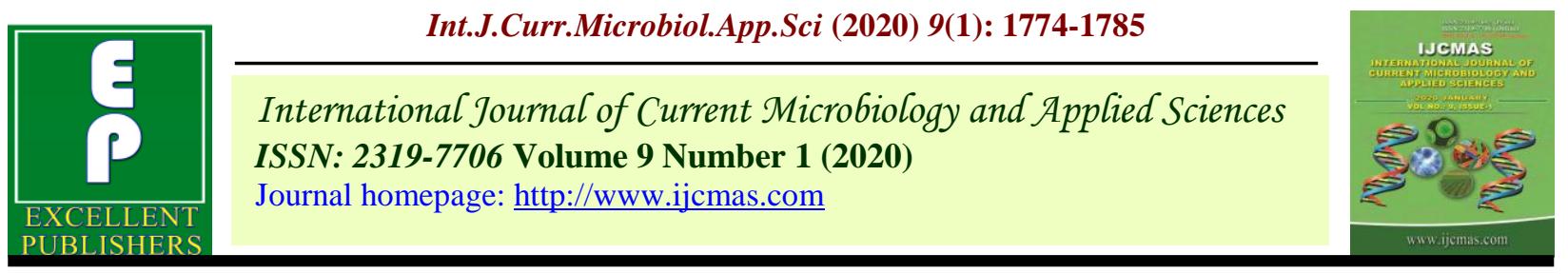

Original Research Article

https://doi.org/10.20546/ijcmas.2020.901.199

\title{
Study on Structural and Technological Change in Accordance with Intergenerational Occupational Mobility in Farming Sector in Tribal and Coastal Districts of Odisha, India
}

\author{
Anshuman Jena*, Kajal Srichandan and A. P. Kanungo \\ Institute of Agricultural Sciences, S'O'A Deemed to be university, Bhubaneswar, India \\ *Corresponding author
}

\begin{tabular}{|l|}
\hline Ke y w o r d s \\
Extension \\
participation, \\
Intergenerational, \\
Structural, \\
Technological, \\
Tribal \\
\hline Article Info \\
\hline Accepted: \\
15 December 2019 \\
Available Online: \\
20 January 2020 \\
\hline \hline
\end{tabular}

\section{A B S T R A C T}

\section{Introduction}

Structural changes in farming refers to changes in land, housing pattern, communication and institutional network, credit facility etc. which are considered as driving forces of changing future agriculture. The structure of agriculture and its food and fibre systems have changed considerably over the past century, reflecting internal and external factors such as institutional, societal (demographic and consumer), technological, 
economic, human capital, and financial causes. The technological changes in farming are associated with change in access and attitude of respondents regarding modern technologies, change in communication network and agri implements possession and extension participation for availing information. Swaminathan (1991) in a study based on panel data collected from households in the Gokilapuram village in south-western Tamil Nadu, found that "agricultural modernisation within the existing structural framework has provided restricted opportunities for occupational change [but] has not mitigated the extreme polarisation in the distribution of land". FAO (2010) stated that some would argue that this movement away from agriculture is a sign of structural transformation of the economy; but the pattern has not brought with it the required job growth needed to absorb the increasing young labor force and as such high levels of underemployment are being experienced in the services and industrial sectors. Campbell (2010) assessed the impact of planned social change and stated that Social implementation, change and impact measurement have to do with the social psychology of interaction between citizens and projects, or between citizens and modes of experimental implementation or between citizens and the special measurement procedures introduced as a part of the evaluation. Mann and Mante (2014) explained the decision to take over a farm with the average agricultural household income in the past years and the number of farms with the patterns of occupational choice. The results demonstrate that a good income situation increases the number of occupational choices in favour for farming, and that occupational choices for farming in turn slow down the structural change. The number of persons who choose a farming career influences the speed of structural change in agriculture.

\section{Materials and Methods}

For the study, total 240 respondents including 120 from coastal and 120 from tribal district of Odisha were chosen from the total population through proportionate random sampling. The total samples were taken from 16 villages in which 8 from coastal and 8 from tribal district on the basis of $10 \%$ proportion from each villages.

Various statistical tools like percentage, mean, standard deviation, cv and regression analysis have been used in this study to make inferences from the collected data on impact of intergenerational occupational mobility in farming sector in coastal and tribal areas of Odisha. ' $\mathrm{C}$ ' is indicating to coastal whereas ' $\mathrm{T}$ ' is indicating tribal area.

\section{Results and Discussion}

The focus here is on the causes or driving forces that change the direction and pace of the structural and technological parameters in the farming sector.

Statistical analysis like percentage, mean and multiple regression analysis were used to find out structural and technological change and its relation with the socio-economic profiles of second generation in tribal and coastal district.

\section{Structural change (Tribal Respondents)}

The table - 2showed higher mean score (32.76) of structure of agriculture in second generation than the first generation (27.88) which proved the prevalence of structural change in agriculture in accordance with the intergenerational occupational mobility among the respondents of tribal district. It indicated that there was significant difference between structure of farming of second generation as compared to first generation. 


\section{Structural change (Coastal Respondents)}

The table no 3 showed higher mean score (37.83) of structure of agriculture in second generation than the first generation (29.88) which proved the prevalence of structural change in agriculture in accordance with the intergenerational occupational mobility among the respondents of coastal district. It was observed that there was significant difference between structure of farming of second generation as compared to first generation.

\section{Change in average land holding (in ha.)}

In the table 4, the sample data resulted that size of average land holding of first generation respondents was 1.71 ha in tribal area which reduced to 1.63 ha with a decrease of 0.08 ha in the second generation. The size of land holding of first generation was 2.18 ha in coastal area which reduced to 2.06 in second generation with a downfall of 0.11 ha. This showed that average land holding was gradually decreasing more in coastal area as compared to the tribal area. This reduction in land holdings has been chiefly due to the family portioning and selling of property to fulfil requirements of family. If the trend persists over the next generation, majority of the farming family will be forced to choose non-farming occupations to maintain their livelihoods.

\section{Change in housing type}

In the table 5 revealed that the mean score of type of house of tribal farmers of first generation was 1.04 which decreased to 1.29 in the second generation and at the same time the mean score of coastal farmers changed from 1.18 to 1.53 with a change of 0.35 which is higher than the tribal district respondents. The government's initiatives to convert the kachha houses to pucca houses, is making good effect on the life of farmers particularly those who are mostly tenants, agricultural labourers and small and marginal farmers.

\section{Communication Network (Tribal District Respondents)}

The table no 6 depicted that the first generation of tribal district was mostly linked with local leaders $(44.17 \%)$ followed by radio (25\%) for getting agricultural information and adopting technologies related to agriculture and allied sector. The second generation opined the importance of input dealers and NGOs (51.67\%) followed by extension agents $(42.50 \%)$ in updating them with the latest information for their development in farming sector which boosted their production and profit from farming.

The intergenerational change resulted sharp decline in communication network of radio ($12.50 \%)$ and local leaders $(-7.50 \%)$ and remarkable positive change in input dealers and NGOs (20.83\%) and ICT(Mobile/Internet) (20.83\%). This showed that the second generation of tribal district are now more dependent on input dealers to gain agricultural information on seeds, fertilisers and insecticides.

The increase in activities of various NGOs for development and uplifting of tribal people have made a remarkable impact on the faith of tribal people. The present generation was more oriented towards virtual world through mobile and internet and these ICT helped them to enrich their knowledge on modern technologies along with various helpful information regarding development in agriculture as well as other sectors. Mobile SMS from state department of agriculture, KVKs and various NGOs on weather forecast and time of cultivation and fertiliser application helped the farmers for proper farm management. 


\section{Communication Network (Coastal District Respondents)}

The table-7 showed that in coastal area the first generation was more dependent on local leaders $(40.83 \%)$ and input dealers $(40.00 \%)$ for seeking agricultural information while the second generation showed their dependency on extension agent (57.50\%) followed by local $(49.17 \%)$. The change trend showed sharp decrease in the communication network of radio $(-25.83 \%)$ while there was increase in the importance of ICT (Mobile/ Internet = $46.67 \%$ ) followed by television $(41.67 \%)$ in coastal area for obtaining information which helped them in adopting new technologies in agriculture and allied sectors.

\section{Institutional Network (Tribal District Respondents)}

From the table 8, the institutional network showed the linkage of tribal people with various institutions surrounding them. This supported that the present generation maintained good network linkage with educational institutions (44.17\%) showing its gradual increase in literacy rate followed by contact with agriculture department $(40.83 \%)$. New initiatives and programmes in agriculture and rural development programmes and new extension strategies made its institutions more accessible to the tribal people now a days. The change result found higher increase in the impact of Krishi Vigyan Kendra (KVK) (28.33\%) through its technology assessment and refinement strategy followed by educational institutes $(24.97 \%)$ and NGOs (23.33\%) among the tribal respondents. Various NGOs are working in tribal areas for social upliftment and gradual increase in income level of farmers from farming sectors played the key role in their social upliftment and improvement in standard of living. The working of NGOs has showed a positive change in the lifestyle of tribal Odisha.

\section{Institutional Network (Coastal District Respondents)}

In the table-9, institutional network showed linkage of coastal respondents with various institutions surrounding them. This found that the present generation witnessed a good network contact with educational institutions $(80.83 \%)$ followed by agriculture department $(56.67 \%)$ and panchayat office $(48.33 \%)$. It indicated towards remarkable increase in literacy rate which ultimately oriented them for better relationship with agriculture department for availing improved agricultural technologies, practices and govt's initiatives through various programmes.

Frequent happening of gram sabha and selection of various beneficiaries through gram sabha had multiplied the importance of panchayat among the respondents of coastal district. The intergenerational change in contacts with institutions showed a remarkable increase in importance of educational institutions $(50.83 \%)$ followed by KVK $(24.17 \%)$. The increase in literacy rate made them more comfortable to select nonfarm occupations rather than doing parental farming occupation due to its minimal social respect and non-profit nature. With comparing the respondents of coastal district with the tribal district, it was found that the impact of NGOs was felt more by the tribal respondents than the costal respondents and the coastal area was dominated by the educational institution.

\section{Extension Participation of respondents (Maximum=3, Minimum=1)}

The table 10 showed that in comparison with tribal respondents, the coastal respondents witnessed larger change in extension participation like attending trainings, demonstrations, field visits and exposure visits etc. The change resulted increase of mean score 0.20 and 0.32 among the 
respondents of tribal and coastal districts from their first generation to second generation respectively in their extension participation.

\section{Change in Extension Participation of respondents across the generation}

From the table no 11, result revealed that 24.17 per cent of tribal district respondents showed higher change in extension participation in comparison to 26.67 per cent of coastal district respondents.

It was found that most of the tribal farmers $(47.50 \%)$ remained in lower level of change in extension participation whereas most of the coastal farmers $(39.17 \%)$ remained in the medium level of change in extension participation which showed better extension participation of the coastal district respondents than the tribal district respondents. This indicated increase in the awareness of the farmers to enhance their capacity building through trainings and demonstration sand exposure visits. The tribal farmers are also in a greater pace in improving their knowledge status by extension participation through the intervention of government organisations and NGOs.

\section{Change in Agri Implements possession (Tribal District Respondents)}

The table 12 showed slow change in possession of power tiller $(7.50 \%)$ followed by water pump $(6.67 \%)$. Most of the tribal farmers $(39.17 \%)$ possessed plough which indicated their backwardness towards mechanisation of farming and at the same time suffered the effect of labour scarcity to perform specific agricultural activities at proper time for which steps need to be taken for orientation of tribal farmers in farm mechanisation in farming.

\section{Change in Agri Implements possession (Coastal District Respondents)}

The table no 13 showed remarkable changes in possession of water pump (17.50\%) followed by power tiller (15.83\%). There was sharp decline in possession of plough ($14.17 \%$ ) with the impact of mechanisation. This is the indication of gradual increase in orientation of coastal farmers towards mechanisation in farming in comparison to tribal farmers.

Respondents' access to modern technologies in farming sector

The table-14 depicted change of mean score in access to modern technologies was 0.29 in tribal and 0.58 in coastal area. The coastal respondents showed dominance over tribal respondents in accessing modern technologies in farming sector. The tribal farmers showed their positive attitude in adopting hybrid maize and some HYVs in rice but were still backward in adopting soil testing, line showing, integrated nutrient management and modern irrigation systems like drip and sprinkler irrigation. The coastal district farmers were well advanced in adoption of these technologies in farming.

Change in respondents' access to modern technologies in farming sector across the generations

The table 15 found that 20 per cent of tribal district respondents and 31.67 per cent of coastal district respondents remained in higher level of change in accessing to modern technologies in farming sector. Majority of tribal farmers $(40.83 \%)$ remained at lower level while majority of coastal farmers $(42.50 \%)$ placed in medium level of change in accessing modern technologies like line sowing, INM, HYVs, Hybrids, IFS, drip irrigation etc. 


\section{Access to credit facility (Tribal District Respondents)}

In the table 16, the credit profile of tribal area dominated by cooperative societies $(40.00 \%)$ instead of landlords in past. The remarkable decline in taking credits from landlords ($42.50 \%$ ) was a good sign for the growth of tribal farmers. Access to better credit facility is an element of better farm planning by the farmers. Large Area Multi-purpose Cooperative Societies (LAMPS) are the facilitating cooperative societies by assisting the tribal farmers in marketing their products and providing interest free short and medium term loans. It's now providing a good helping hand for the development of the tribal farmers. But with comparison to coastal credit system, tribal farmers needs to be more aware and cooperative societies and banks should take more innovative steps to include the needy farmers so that small and marginal farmers can be benefitted more. Still a large percentage of farmers showed their dependency for credit facility on landlords $(38.33 \%)$ and farmers with outstanding loans associated with higher interest would be under pressure to repay and tend to dislike the occupation.

\section{Access to credit facility (Coastal District Respondents)}

From the table-17, it was found that the credit profile of coastal area was dominated by both cooperative societies (51.67\%) and banks $(42.50 \%)$. The cooperative societies run by Primary Agricultural Cooperative Societies (PACS) is leading the credit facilities provision in coastal area followed by different government and private nationalised banks. It was also observed that the coastal respondents witnessed the importance of self-help groups as the informal source of credit facilities in rural areas.
Multiple regression analysis of socioeconomic variables of second generation respondents with the structural and technological change in farming sector

The table-18 revealed that the independent socio-economic variables like age, education, occupation and progressiveness of the secondgeneration respondents have contributed the highest variance to the dependent variable structural and technological change in farming sector with respect to the change in generation. The young generation with higher educational status helped in changing the structure of both agriculture and rural society. While most of the educated youth were opting for better occupation from their previous generation for higher status and income but still with the involvement of educated youth in farming sector, the structure of farming sector is gradually changing by adopting farm mechanisation and modern technologies in farming with the support of better credit facilities. Progressiveness made the farmers updating themselves with latest technologies and increased the adoption rate of new technologies in farming and allied sectors.

Among the 12 variables, age, education, occupation and progressiveness of secondgeneration respondents had recorded significant regression impact upon structural and technological change in accordance with intergenerational occupational mobility of the all respondents in farming sector. The $r$ square value being 0.384 , it is concluded that the conglomeration of the causal factors together has attributed to 38.4 per cent. So, it can be concluded that the socio-economic variables of first generation had considerable influence in accelerating intergenerational occupational mobility among the respondents of farming sector. This finding is supported by the findings of Mann and Mante (2004) who observed that a good income situation increases the number of occupational choices 
in favour for farming, and that occupational choices for farming in turn slow down the structural change. The number of persons who choose a farming career influences the speed of structural change in agriculture.

Table.1 Sampling procedure (Multistage Random Sampling)

\begin{tabular}{|c|c|c|c|}
\hline Step & Items & Level & Approach \\
\hline 1 & State (1) & Odisha & Purposive \\
\hline 2 & District (2) & $\begin{array}{l}\text { Jagatsinghapur(Coastal) } \\
\text { Mayurbhanj(Tribal) }\end{array}$ & Random \\
\hline 3 & Block (4) & Kujang, Tirtol, Kaptipada, Bangiriposi & Random \\
\hline 4 & $\begin{array}{l}\text { Gram } \\
\text { Panchayat } \\
(16)\end{array}$ & $\begin{array}{l}\text { Bad bisole, Badgudugudia, Notto, Sarat, Sorisapal, Bangiriposi, } \\
\text { Nischinta, Dighi, Bagoi, Talapada, Zillanasi, Badabalikani, } \\
\text { Amberi, Gopalpur, Katra, Patilo }\end{array}$ & Random \\
\hline 4 & Village(16) & $\begin{array}{l}\text { Bhalubasa, Benipur Notto Gourchandrapur, Betjharan, Kalliami, } \\
\text { Nischinta, Darakantia, Sandhapur, Talapada, Saharadia, } \\
\text { Badabalikani, Arilo, Derakana, Jaganathpur, Kotian }\end{array}$ & Random \\
\hline 5 & $\begin{array}{l}\text { Respondents } \\
(240)\end{array}$ & $\begin{array}{l}120(\text { Tribal }) \\
120(\text { Coastal })\end{array}$ & $\begin{array}{l}\text { Proportionate } \\
\text { Random }\end{array}$ \\
\hline
\end{tabular}

Table.2 Structural change (Tribal Respondents)

\begin{tabular}{|l|l|l|l|l|l|l|}
\hline & Mean & $\mathbf{N}$ & Std. Deviation & Std. Error Mean & T value & Sig. \\
\hline $\begin{array}{l}\text { Structure of Agriculture } \\
\text { (1" generation })\end{array}$ & 27.88 & 120 & 1.73 & 0.16 & -10.99 & 0.00 \\
\hline $\begin{array}{l}\text { Structure of Agriculture } \\
\left(2^{\text {nd }} \text { generation }\right)\end{array}$ & 32.76 & 120 & 5.42 & 0.49 & & \\
\hline
\end{tabular}

Table.3 Structural change (Coastal Respondents)

\begin{tabular}{|l|c|c|c|c|c|c|}
\hline & Mean & $\mathbf{N}$ & Std. Deviation & Std. Error Mean & T value & Sig. \\
\hline $\begin{array}{l}\text { Structure of Agriculture } \\
\left(1^{\text {s }} \text { generation }\right)\end{array}$ & 29.88 & 120 & 2.76 & 0.25 & -11.36 & 0.000 \\
\hline $\begin{array}{l}\text { Structure of Agriculture } \\
\left(2^{\text {nd }} \text { generation }\right)\end{array}$ & 37.83 & 120 & 9.31 & 0.85 & & \\
\hline
\end{tabular}

Table.4 Change in average land holding (in ha.)

\begin{tabular}{|l|c|c|c|}
\hline \multirow{2}{*}{} & \multicolumn{2}{|c|}{ Mean Score } & Change in Mean \\
\cline { 2 - 4 } & $\begin{array}{c}\text { 1st generation } \\
(\mathrm{N}=120)\end{array}$ & $\begin{array}{c}\text { 2nd generation } \\
(\mathrm{N}=120)\end{array}$ & score \\
\hline Tribal District & 1.71 & 1.63 & -0.08 \\
\hline Coastal District & 2.18 & 2.06 & -0.11 \\
\hline
\end{tabular}


Table.5 Change in housing type

\begin{tabular}{|l|c|c|c|}
\hline & \multicolumn{2}{|c|}{ Mean Score } & Change in Mean \\
& $\begin{array}{c}\text { 1st generation } \\
\text { score }\end{array}$ & $\begin{array}{c}\text { 2nd generation } \\
(\mathrm{N}=120)\end{array}$ & \\
\hline Tribal District & 1.04 & 1.29 & 0.25 \\
\hline Coastal District & 1.18 & 1.53 & 0.35 \\
\hline
\end{tabular}

Table.6 Communication Network (Tribal District Respondents)

\begin{tabular}{|c|c|c|c|}
\hline & \multicolumn{3}{|c|}{ Frequency (Percentage) } \\
\hline & 1st Generation & 2nd Generation & Change \\
\hline Local leaders & $53(44.17 \%)$ & $44(36.67 \%)$ & $-9(-7.50 \%)$ \\
\hline $\begin{array}{l}\text { Input } \\
\text { dealer/NGOs }\end{array}$ & $37(30.83 \%)$ & $62(51.67 \%)$ & $25(20.83 \%)$ \\
\hline Newspaper & $5(4.17 \%)$ & $19(15.83 \%)$ & $14(11.67 \%)$ \\
\hline Radio & $30(25.00 \%)$ & $15(12.50 \%)$ & $-15(-12.50 \%)$ \\
\hline Television & $4(3.33 \%)$ & $25(20.83 \%)$ & $21(17.50 \%)$ \\
\hline Extension agent & $29(24.17 \%)$ & $51(42.50 \%)$ & $22(28.33 \%)$ \\
\hline $\begin{array}{l}\text { ICT(Mobile/Inter } \\
\text { net) }\end{array}$ & 0 & $25(20.83 \%)$ & $25(20.83 \%)$ \\
\hline
\end{tabular}

Table.7 Communication Network (Coastal District Respondents)

\begin{tabular}{|l|c|c|c|}
\hline & \multicolumn{3}{|c|}{ Frequency (Percentage) } \\
\hline Local leaders & 1st Generation & 2nd Generation & Change \\
\hline Input dealer/NGOs & $49(40.83 \%)$ & $59(49.17 \%)$ & $10(8.33 \%)$ \\
\hline Newspaper & $48(40.00 \%)$ & $\mathbf{7 2}(\mathbf{6 0 . 0 0 \%})$ & $24(20.00 \%)$ \\
\hline Radio & $11(9.17 \%)$ & $43(35.83 \%)$ & $32(26.67 \%)$ \\
\hline Television & $44(36.67 \%)$ & $13(10.83 \%)$ & $\mathbf{- 3 1}(-\mathbf{2 5 . 8 3 \% )})$ \\
\hline Extension agent & $9(7.50 \%)$ & $59(49.17 \%)$ & $\mathbf{5 0}(\mathbf{4 1 . 6 7 \% )})$ \\
\hline ICT(Mobile/Internet) & $36(30.00 \%)$ & $69(57.50 \%)$ & $33(27.50 \%)$ \\
\hline
\end{tabular}

Table.8 Institutional Network (Tribal District Respondents)

\begin{tabular}{|l|c|c|c|}
\hline \multirow{2}{*}{ Agril. Dept. } & \multicolumn{3}{|c|}{ Frequency (Percentage) } \\
\cline { 2 - 4 } & 1st Generation & 2nd Generation & Change \\
\hline KVK & $\mathbf{3 2}(\mathbf{2 6 . 6 7 \%})$ & $49(40.83 \%)$ & $17(14.17 \%)$ \\
\hline Block Office & $3(2.50 \%)$ & $37(30.83 \%)$ & $\mathbf{3 4} \mathbf{( 2 8 . 3 3 \% )}$ \\
\hline Educational Inst. & $14(11.67 \%)$ & $24(20.00 \%)$ & $10(8.33 \%)$ \\
\hline Panchayat & $23(19.20 \%)$ & $\mathbf{5 3}(\mathbf{4 4 . 1 7 \%})$ & $30(24.97 \%)$ \\
\hline NGOs & $26(21.68 \%)$ & $46(38.33 \%)$ & $20(16.67 \%)$ \\
\hline
\end{tabular}


Table.9 Institutional Network (Coastal District Respondents)

\begin{tabular}{|l|c|c|c|}
\hline & \multicolumn{3}{|c|}{ Frequency (Percentage) } \\
\cline { 2 - 4 } & 1st Generation & 2nd Generation & Change \\
\hline Agril. Dept. & $\mathbf{4 5}(\mathbf{3 7 . 5 0 \%})$ & $68(56.67 \%)$ & $23(19.17 \%)$ \\
\hline KVK & $15(12.50 \%)$ & $44(36.67 \%)$ & $29(24.17 \%)$ \\
\hline Block Office & $11(9.17 \%)$ & $31(25.83 \%)$ & $20(16.67 \%)$ \\
\hline Educational Inst. & $36(30.00 \%)$ & $\mathbf{9 7}(\mathbf{8 0 . 8 3 \%})$ & $\mathbf{6 1}(\mathbf{5 0 . 8 3 \%})$ \\
\hline Panchayat & $37(30.83 \%)$ & $58(48.33 \%)$ & $21(17.50 \%)$ \\
\hline NGOs & $11(9.17 \%)$ & $30(25.00 \%)$ & $19(15.83 \%)$ \\
\hline
\end{tabular}

Table.10 Extension participationof respondents (Maximum=3, Minimum=1)

\begin{tabular}{|l|c|c|c|}
\hline & \multicolumn{3}{|c|}{ Mean Score } \\
\cline { 2 - 4 } & 1st Generation & 2nd Generation & Change \\
\hline Tribal District Respondents & 1.15 & 1.35 & 0.20 \\
\hline Coastal District Respondents & 1.26 & 1.58 & 0.32 \\
\hline
\end{tabular}

Table.11 Change in Extension Participation of respondents across the generation

\begin{tabular}{|c|c|c|}
\hline & Tribal District & Coastal District \\
\hline High (Mean + 1/2SD) & $29(24.17 \%)$ & $32(26.67 \%)$ \\
\hline Medium $\left(\right.$ Mean $\left.+\_1 / 2 S D\right)$ & $34(28.33 \%)$ & $47(39.17 \%)$ \\
\hline Low $($ Mean - 1/2SD) & $57(47.50 \%)$ & $41(34.17 \%)$ \\
\hline
\end{tabular}

Table.12 Change in Agri Implements possession (Tribal District Respondents)

\begin{tabular}{|l|c|c|c|}
\hline \multirow{2}{*}{ Implements } & \multicolumn{3}{|c|}{ Frequency (Percentage) } \\
\cline { 2 - 4 } Tractor & 1st generation & 2nd generation & Change \\
\hline Power Tiller & 0 & $2(1.67 \%)$ & $2(1.67 \%)$ \\
\hline Water pump & 0 & $9(7.50 \%)$ & $\mathbf{9 ( 7 . 5 0 \% )}$ \\
\hline weeder & $6(5 \%)$ & $14(11.67 \%)$ & $8(6.67 \%)$ \\
\hline Plough & 0 & $5(4.17 \%)$ & $5(4.17 \%)$ \\
\hline
\end{tabular}

Table.13 Change in Agri Implements possession (Coastal District Respondents)

\begin{tabular}{|l|c|c|c|}
\hline \multirow{2}{*}{ Implements } & \multicolumn{3}{|c|}{ Frequency (Percentage) } \\
\cline { 2 - 4 } & 1st generation & 2nd generation & Change \\
\hline Tractor & $2(1.67 \%)$ & $4(3.33 \%)$ & $2(1.67 \%)$ \\
\hline Power Tiller & 0 & $19(15.83 \%)$ & $19(15.83 \%)$ \\
\hline Water pump & $13(10.83 \%)$ & $34(28.33 \%)$ & $21(17.50 \%)$ \\
\hline weeder & 0 & $12(10.00 \%)$ & $12(10.00 \%)$ \\
\hline Plough & $71(59.17)$ & $54(45.00 \%)$ & $\mathbf{- 1 7 ( - 1 4 . 1 7 \% )}$ \\
\hline
\end{tabular}


Table.14 Respondents' access to modern technologies in farming sector (Maximum=3, Minimum=1)

\begin{tabular}{|l|c|c|c|}
\hline & \multicolumn{3}{|c|}{ Mean Score } \\
\cline { 2 - 4 } & 1st Generation & 2nd Generation & Change \\
\hline Tribal District Respondents & 1.02 & 1.31 & 0.29 \\
\hline Coastal District Respondents & 1.05 & 1.63 & 0.58 \\
\hline
\end{tabular}

Table.15 Change in respondents' access to modern technologies in farming sector across the generations

\begin{tabular}{|c|c|c|}
\hline & Tribal District & Coastal District \\
\hline High $($ Mean $+1 / 2 \mathrm{SD})$ & $24(20.00 \%)$ & $38(31.67 \%)$ \\
\hline Medium $\left(\right.$ Mean $\left.+\_1 / 2 \mathrm{SD}\right)$ & $47(39.17 \%)$ & $51(42.50 \%)$ \\
\hline Low $($ Mean $-1 / 2 \mathrm{SD})$ & $49(40.83 \%)$ & $31(25.83 \%)$ \\
\hline
\end{tabular}

Table.16 Access to credit facility (Tribal District Respondents)

\begin{tabular}{|l|c|c|c|}
\hline \multirow{2}{*}{ Credit Sources } & \multicolumn{3}{|c|}{ Frequency (Percentage) } \\
\cline { 2 - 4 } & 1st generation & 2nd generation & Change \\
\hline Landlords & $97(80.83 \%)$ & $46(38.33 \%)$ & $\mathbf{- 5 1 ( - 4 2 . 5 0 \% )}$ \\
\hline Friends & $42(35.00 \%)$ & $39(32.50 \%)$ & $-3(-2.50 \%)$ \\
\hline SHGs & 0 & $24(20.00 \%)$ & $24(20.00 \%)$ \\
\hline Cooperative societies & $8(6.67 \%)$ & $\mathbf{4 8}(\mathbf{4 0 . 0 0 \% )}$ & $\mathbf{4 0}(\mathbf{3 3 . 3 3 \%})$ \\
\hline Bank & $7(5.83 \%)$ & $25(20.83 \%)$ & $18(15.00 \%)$ \\
\hline
\end{tabular}

Table.17 Access to credit facility (Coastal District Respondents)

\begin{tabular}{|l|c|c|c|}
\hline \multirow{2}{*}{ Credit Sources } & \multicolumn{3}{|c|}{ Frequency (Percentage) } \\
\cline { 2 - 4 } & 1st generation & 2nd generation & Change \\
\hline Landlords & $78(65.00)$ & $16(13.33 \%)$ & $\mathbf{- 6 2 ( - 5 1 . 6 7 \% )}$ \\
\hline Friends & $53(44.17 \%)$ & $38(31.67 \%)$ & $-15(-12.50 \%)$ \\
\hline SHGs & 0 & $30(25.00 \%)$ & $30(25.00 \%)$ \\
\hline Cooperative societies & $19(15.33 \%)$ & $\mathbf{6 2}(\mathbf{5 1 . 6 7 \%})$ & $\mathbf{4 3 ( 3 5 . 8 3 \% )}$ \\
\hline Bank & $22(18.33 \%)$ & $\mathbf{5 1}(\mathbf{4 2 . 5 0 \% )}$ & $29(24.17 \%)$ \\
\hline
\end{tabular}


Table.18 Multiple regression analysis of socio-economic variables of second generation respondents with the structural and technological change in farming sector

\begin{tabular}{|c|c|c|c|c|c|}
\hline & \multicolumn{2}{|c|}{$\begin{array}{l}\text { Unstandardized } \\
\text { Coefficients }\end{array}$} & \multirow{2}{*}{$\begin{array}{c}\text { Standardized } \\
\text { Coefficients } \\
\text { Beta }\end{array}$} & \multirow[t]{2}{*}{$\mathrm{t}$} & \multirow[t]{2}{*}{ Sig. } \\
\hline & B & Std. Error & & & \\
\hline & $\begin{array}{c}34.53 \\
2\end{array}$ & 3.549 & & 9.730 & .000 \\
\hline Age & 2.471 & .309 & .504 & 8.005 & $.000 * *$ \\
\hline Education & .775 & .311 & .181 & 2.494 & $.013 * *$ \\
\hline Occupation & -.664 & .275 & -.216 & -2.412 & $.017 * *$ \\
\hline Family size & -.610 & .640 & -.053 & -.953 & .341 \\
\hline Land Holding & .410 & .474 & .103 & .865 & .388 \\
\hline Housing type & -.476 & .895 & -.038 & -.531 & .596 \\
\hline Annual Income & .484 & .479 & .100 & 1.011 & .313 \\
\hline Credit facility & -.246 & .343 & -.043 & -.717 & .474 \\
\hline $\begin{array}{l}\text { Communication } \\
\text { Network }\end{array}$ & -.385 & .236 & -.121 & -1.631 & .104 \\
\hline $\begin{array}{l}\text { Institutional } \\
\text { Network }\end{array}$ & .007 & .270 & .002 & .025 & .980 \\
\hline Market linkage & .383 & .449 & .059 & .853 & .395 \\
\hline Cosmopoliteness & .048 & .241 & .016 & .200 & .842 \\
\hline $\begin{array}{l}\text { Extension } \\
\text { Participation }\end{array}$ & .155 & .183 & .066 & .847 & .398 \\
\hline Progressiveness & -.374 & .187 & -.163 & -2.006 & $.046 * *$ \\
\hline \multicolumn{6}{|c|}{ Dependent Variable: Structural and technological change } \\
\hline Model & $\mathrm{R}$ & R Square & Adjusted R Square & \multicolumn{2}{|c|}{ Std. Error of the Estimate } \\
\hline 1 & .569 & .384 & .282 & \multicolumn{2}{|c|}{3.377} \\
\hline
\end{tabular}

In conclusion, there was significant difference between structure of farming of second generation as compared to first generation both in tribal and coastal district. The coastal district witnessed higher change in mean score of structural change in farming sector than the tribal district. The intergenerational change resulted sharp decline in communication network of radio $(-12.50 \%)$ and local leaders $(-7.50 \%)$ and remarkable positive change in input dealers and NGOs (20.83\%) and ICT(Mobile/Internet) (20.83\%) in tribal district whereas in coastal district, there was decrease in the communication network of radio $(-25.83 \%)$ and increase in the importance of ICT(Mobile/Internet$46.67 \%$ ) followed by television (41.67\%) for obtaining information which helped them for adopting new technologies in agriculture and allied sectors. Most of the tribal farmers (47.50\%) remained in lower level of change in extension participation whereas most of the coastal farmers $(39.17 \%)$ remained in the medium level of change in extension participation. The result depicted change of mean score in access to modern technologies in farming was 0.29 in tribal and 0.58 in coastal area. The coastal respondents showed 
dominance over tribal respondents in accessing modern technologies in farming sector. The variables like age, education, occupation and progressiveness of secondgeneration respondents had recorded significant regression impact upon structural and technological change in accordance with intergenerational occupational mobility in farming sector.

\section{References}

Campbell DT. 2010. Assessing the Impact of Planned Social Change, Journal of Multidisciplinary Evaluation, 7(15): 343.
FAO. 2010. Global strategy to improve agricultural and rural statistics.

Majumder R. 2010. Intergenerational mobility in educational \& occupational attainment: a comparative study of social classes in India. SAGE Publications India Private Limited, 4(4): $1-27$

Mann S and Mante J. 2014. Occupational Choice and Structural Change, Working Paper Series No. 2.

Swaminathan M. 1991. Gainers and losers: a note on land and occupational mobility in a south Indian village, 22: 261-277.

\section{How to cite this article:}

Anshuman Jena*, Kajal Srichandan and A. P. Kanungo. 2020. Study on Structural and Technological Change in Accordance with Intergenerational Occupational Mobility in Farming Sector in Tribal and Coastal Districts of Odisha, India. Int.J.Curr.Microbiol.App.Sci. 9(01): 1774-1785. doi: https://doi.org/10.20546/ijcmas.2020.901.199 